\title{
Repositioning the Local Wisdom towards the National Curriculum
}

\author{
Moh. Yamin \\ Lambung Mangkurat University \\ Banjarmasin, Indonesia \\ moh_yamin@unlam.ac.id
}

\author{
Wahyu \\ Lambung Mangkurat University \\ Banjarmasin, Indonesia
}

\begin{abstract}
- the future challenge in creating and building the strong education toward national curriculum should be based on the local wisdom. The local wisdom here relates to life values coming from the grass root life. The capability and flexibility of curriculum adapting to the era change occur when the local wisdom as the life movement is implemented and inserted in each of curriculum development and its use. This paper has the objective to identify the local wisdom materials, to analyze their positions contributing to national curriculum building, and to reformulate the framework of curriculum development based on the local wisdom. The method used in this research is theoretical review with a qualitative approach. The additional data to complete and perfect the theoretical review analysis is based on the secondary data relating to the local wisdom. The research result states that the local wisdom values such as tolerance, mutual cooperation, and traditional herb are the glue to maintain the unity of the nation indifference and variety. Such local wisdom values should be integrated into the national curriculum so that the classroom activities are able to contribute towards the embedment of local values to students.
\end{abstract}

Keywords - local wisdom; education; the national curriculum

\section{INTRODUCTION}

The future challenge that should be faced in education is its role in guiding the generation and nation to be civilized. Education as the main capital in creating the strongcharacterized generation should be started by accelerating the education role in all aspects. UNESCO (United Nations, Educational, Scientific and Cultural Organization) publishes that there are four pillars in education progress for long-term interest and those are that education has the objective so that all learn to know, learn to do, learn to be, and learn to live together [1]. Those combine all objectives of education coming from IQ, EQ dan SQ. For further explanation, here are the explanations:

- Learning to know means that every person has the right and obligation to know everything relating to his or her life to do in the next life that implicates to his or her interest or collective interest. Becoming a person or human being must be understood that he or she was involved in every activity to know what to know.

- Learning to do means that what every person knows relating to the good deed to build a nation should be implemented because it deals with actions. What he or she knows not only to know, but also to practice so that the value of knowledge can spread into life values for all. Knowing anything dealing with what should be done and forbidden must be formulated in activities supporting the collective deeds. By doing that, the good nation will be created and all can be part of that thing.

- Learning to mean that becoming a human being is in the process. To achieve an ideal human being, it must be based on circle life that is begun from learning to do. It means that becoming a human being should be able to interpret everything he or she knows to internalize.

- Learning to live together has the objective that when every person knows what to know, learns what to do, and learns to be, it should be continued with the capacity to learn to live together. This last point is something difficult to apply because of some considerations and one of them commonly relates to a difference of language, race, religion, and skin color. Such obstacle so far colorizes the persons' path and life wherever they are. In as much as learning to live together is the difficult and complicated goal to achieve, this can be the new challenge to face collectively that difference should be the tie to create the peaceful life by respecting together. Under the flag of difference, there must be a spirit to tie the values of humanism that all human beings in any varieties are one.

Based on that analysis, there is one single paradigm to have that every one of us should learn to know each other, to remind each other when we are in the wrong way what has been done and what should be conducted in the next time. The Constitution 1945 Article 31, paragraph 3 says that "The government shall manage and organize a national education system, which enhances faith and piety and noble in order to achieve the moral life of the nation being governed by the law" signals the importance of education for building the nation. The education role to guide and change the nation into the better one actually should be formulated the details. The education existence for nation pillar determines the nation path where to go for the next step [2].

Ref. [3] that states "National Education has the main task to develop the ability, character, and civilization of the dignity nation in enlighting the nation life being aimed at developing students' potency in order to become the faithful, noble, healthy, knowledgeable, skillful, creative, independent, democratic, and responsible a man" supports the education role fully in nation-building. 
The education position based on such considerations must be put at the central and strategic milestones in nation-building. Education in nation building and involves in it will not be away from the effort of the national curriculum that should be paid attention because the national curriculum is the reflection on how the education is designed to answer the nation needs and the urgency in building the life order in the education aspect. Designing the nation through education deals with the values that should be inserted in the national curriculum itself as the main points that must not be removed in the run of national life. There will be many things that will exist in determining the way of national life. One of it is local wisdom that is the inner life reflection coming from the daily life of the people themselves. Local wisdom is anything valuable and life guide in bringing the people wise and civilized.

This study has the objective to identify the local wisdom materials, to analyze their positions contributing to national curriculum building, and to reformulate the framework of curriculum development based on the local wisdom. The significance of this study is for contributing the values of local wisdom to curriculum design for international benefit and interest. The contributions can be meant as the effort to support the national interest in which local wisdom based education is expected to be the capital in developing the education management that is based on the local objective, but orients to national interest so that such contribution can be beneficent for educational progress.

\section{LITERATURE REVIEW}

\section{A. The Philosophy of Education}

Education should be meant as the capital to build the civilized nation. The education context being positioned as the tool and media for building the nation should be looked at one paradigm in order to celebrate the process of education for all and to imprint any values valuable for a civilized nation. Understanding the education itself cannot stand itself, but it is to involve the root of education as the mother of education called the philosophy of education.

Kilpatrick states that "philosophizing and education are, then, but two stages are in the same endeavor; philosophizing is to think out better values and idealism, and education is to realize these in lives in human personality [4]. It means that philosophy of education endeavors to show the values of life that should be integrated into teaching and learning activities that are formulated and actualized in any series of classes. There will not be values imprinting in the classroom towards students if the educational philosophy is not the standpoint in conducting the civilized education for all. The good implementation of education for educating will happen and achieve the target when all apparatuses and materials have been prepared to teach by inserting them into the instructional material.

As the supporting detail, Lodge also states that to live is education and education are to live [5]. It means that everyone who lives actually is implementing the education and every activity the person does illustrate the education itself. In further explanation, every human being when partaking in every program of their live signals the process of education to know what to know, to understand what to understand, to do what to do, and so soon. The sentence "Live is education" mentions that human lives for learning. They learn to be educated and to be educated must be in the learning process. There is no education without learning process in which they must make any mistakes. By doing any mistakes, they learn to do the better ones and it will be the education process. The sentence "education is to live" means that human learn by education for living. By education, they do the process for good and better living. Consequently, education for those in living is the enlightenment and enlightening program to humanize the human beings.

What Lodge says above can be considered that education philosophy teaches the values for the involved in nationbuilding. Education philosophy positions the basic entries informing and creating human being existences as the civilized persons towards the civilized nation. Muhammad al-Taomi alSyaibani in strengthening such those mentions three benefits of learning education philosophy as follows [6]:

- Education philosophy assists the curriculum designers and thinkers in formulating and forming the objectives and goals of education system, including the objectives and assessment indicators on learning achievement in teaching and learning program in one period;

- Education philosophy is the best guide to assessing the education achievement globally. The assessment deals with all programs what the school plans and does;

- Education philosophy assists in studying the spiritual, culture, social, economy, and political aspect in supporting the education progress.

\section{B. National Education in the Perspective of State}

The task of celebrating the national education is that the state has the responsibility to manage the education from the basic up to higher education level. The people's right to get the education access should be facilitated so that every one of them as the young generation in productive age from seven to seventeen can get the education service. Education service becomes the legal and formal duty that should be fulfilled for public interest and national interest.

Here are several legal formal considerations used that education access for all is the necessity:

- The Constitution of Article 311945 states that every citizen has the right to access the education; every citizen is obliged to involve in basic education and the state has the obligation to facilitate the fund; the state endeavors to implement the national education system based on piousness, faithfulness, and nobility increasing to enlight the nation life; the state prioritizes the education budgeting in 20 percent in national and local budget in order to fulfill the national education program; and the state endeavors to advance the science and technology by respecting the values religion and national unity for civilization progress and human prosperity [2]; 
- Ref. [3] about National Education System on Article 1 verse 1 states that education is the conscious and planned effort to embody the learning situation and learning process so that the learners can develop their potencies actively to have the spiritual religious strength, selfcontrol, personality, intelligence, good behaviour and life skill for their interest, society, nation, and state;

- $\quad$ Ref. [7] about Education National Standard on Article 1 states that national education standard is about the minimal criteria in this republic.

\section{National Curriculum and Local Curriculum}

National education as nation-building tool has the vision for embodying the strong social indignity to empower all citizens so that they can respond the era challenge in the next phase. The education implementation based on [3] about national education system can guide the process of qualified students that can determine the path of the nation in the next time. As the part of the education system, the curriculum has the significant and central role in contributing the quality process of educating the students. A curriculum that is nationally developed and planned has the purpose of developing the students' potency into the qualified and civilized persons. The competency-based curriculum as the national reference in implementing the national education in this republic guides the education achievement for the students in order to be the ones who are qualified to respond the future challenges; to be the ones who are educated, pious, healthy, knowledgeable, capable, independent, and creative; and to be the responsible citizens towards their tasks.

As the implementation of national education curriculum, it should have the basic local support so that the goal of national education can be achieved. The success of national educational and its implementation should be supported by the local details to accelerate the goal of national education that is called the local curriculum. The local curriculum functions to bridge the national interest to apply in the local area through the local curriculum. It works by spreading and imprinting the local values in line with the national education perspectives and interests. It attends to accumulate all potencies in local content to combine with the national curriculum. The local curriculum commonly called local content based on [3] about the national education system is the study intended to form the students' comprehension and perception towards the potency in which they live. In the Act on 32, 2005 about National Standard Article $77 \mathrm{~N}$ (The Act number 32, 2005 about National Standard), juncto on number 19, 2005 (The Act number 32, 2005 about National Standard), juncto on number 19, 2005) states that local content for every level of education contains the potencies and local uniquenesses about learning process. Those can be developed and implemented at every level of education.

Those things can be useful for students' knowledge, behavior, and skill so that they:

- Know and become more familiar with their environment socially and culturally;
- Have the capability and skill as well as knowledge about their region that are useful for themselves and their environment; and

- Own the behaviors in line with the values and norms based on being available in their local regions. By having those, it can maintain the ancestor values to support the nation-building.

\section{Local Wisdom}

Local wisdom is the knowledge being discovered or acquired by local people through the accumulation of experience in trials and it is integrated by understanding the surrounding nature and culture. Local wisdom is dynamic by functioning the local wisdom that is connected to the global situation [8]. Local wisdom is the live view, science, and any kinds of life that is manifest in any activities the local people do to respond the life problem in order to solve their problems [9]. According to [10], local wisdom is the human intelligence in one ethnic community obtained through their life experiences. The form of local wisdom is commonly into the idea, social activities, and artifact [11].

Here is the local wisdom that can be the material to design the local curriculum towards the national curriculum:

- Aceh: Udep tsare mate syahid (to live happily, dying because of Allah SWT), Hukom ngon adat lagge zat ngon sifeut (between law and norm is like substance and its characteristics).

- Melayu (Deli, Kalimantan Barat, Sibolga, Sumatra Barat): the different place is different fish in which we are, let us respect the place.

- Batak: Hasangapon, hagabeon, hamoraon, sarimatua (dignity, property, spread generation, perfect life). Nilakka tu jolo sarihon tu pudi (go a step forward considers the back step move).

- Sumatra Barat: Bulek ai dek pambuluah, bulek kato jo mupakkek (round water for the vessel, a spherical word with consensus); Adat ba sandi syara', syara' ba sandi kitabullah (the norm is based on law; the law is based on holybook).

- Wamena: Weak Hano Lapukogo (sad and and happy collectively); Ninetaiken O'Pakeat (one hears in one taste).

- Bugis: Sipakatau (reminding each other); Sipakalebbi (respecting each other); Mali Siparappe, Rebba Sipatokkong (reminding each other, respecting each other, promoting each other).

- Manado: Baku Beking Pandei (learning each other to be better).

- $\quad$ Minahasa: Torang Samua Basudara (we are in friendship); Mapalus (mutual cooperation); Tulude-Maengket (voluntary work for being harmonious), Baku-baku bae, bakubaku sayang, baku-baku tongka, bakubaku kase inga (love, guide-lead, and remember to remind each other); Sitou Timou, Tumou Tou (supporting each other and to live for living: human life for the other).

- Bolaang Mangondow: Momosat (cooperation); Moto tabian, moto tampiaan, moto tanoban (to love, to improve and to miss each other). 
- Kaili: Kitorang bersaudara (friendship); Toraranga (to remind each other), Rasa Risi Roso Nosimpotobe (to be in heart, perception, one place, and one way).

- Poso: (Suku Pamona, Lore, Mori, Bungku dan Tojo/UnaUna, Ampana dan pendatang: Bugis, Makassar, Toraja, Gorontalo, Minahasa, Transmigrasi: Jawa, Bali, Nusa Tenggara): Sintuwu Maroso (it is the solid unity: Although there are many problems, nobody can separate the Poso without race, religion difference).

- Sulawesi Tenggara: Kolosara (supremacy of Samaturu (Bahasa Tolala): Unity, mutual cooperation, respecting each other; Depo adha adhati (Muna): honoring each other.

- Bali: Manyama braya (all are in family), Tat Twam Asi (to be in the same goat), Tri Hita Karana (three causes of happiness), Pariangan (being harmonious with the God), Pawongan (being harmonious with the human), and Palemahan (being harmonious with the nature).

- Jambi: Lindung melindung bak daun sirih, Tudung menudung bak daun labu, Rajut merajutbak daun petai (helping each other /respecting each other).

- Jawa Timur: Siro yo ingsun, ingsun yo siro (egalitarianism), Antarantaran ugo (friendship).

- Pandeglang: Saman functions as art, meditation; a way of remembrance and sobriety, and symbols in magical power [12]. Through Saman activities, the Pandeglang can create the harmony, mutual cooperation in peace in building the social togetherness and religiosity among the people, especially the Saman people that orients to live together.

- Kalimantan Selatan: Kayuh baimbai (mutual cooperation), Gawi sabumi (mutual cooperation), Basusun Sirih (unity), Menyisir sisi tapih (introspection).

- Dayak Kanayatri: Adil ka'talimo, bacuramin ka'saruga, ba sengat ka'jubata (wise for all, heavenly mirror, depending on the God); Rumah Betang (together and being tolerant each other); Handep-habaring hurung (together and mutual cooperation values); Betang (spirit of long house).

- Dayak Bekati: Janji baba's ando (the promise must be implemented); Janji pua' take japu (the promise is only the words).

- Dayak Bahau: Murip ngenai (prosperous); Te'ang liray (superior: sportive competition).

Those values above coming from local wisdom from different places and regions in this republic are the richness of nation in maintaining the national unity in diversity. Those values are the national capital in order to teach to all children in all ages, especially for those who are categorized the productive age for learning. The diversities of local wisdom that have been elaborated with the valuable meaning can deliver the social and spiritual messages and they can be educative when those are inserted in teaching and learning activities. The teaching and learning activities can be manifest in a number of programs that support the goal and objective of schooling.

In a word, local wisdom in many different terms being based on the region where they are from should be considered as the power of the nation in creating and building the awareness of local wisdom behalf on public interest. It means that when all students in the different age of different level of education have the same point of view about the importance of learning the local wisdom, such thing can colorize their behavior and mindset that every region in this republic has the uniqueness and it is the main factor that strengthens the national unity. The nation unity happens because of the same perception in comprehending the difference of way of life. The way of life deals with the local wisdom that forms and underlies every person in a different region in thinking, behaving, and acting. The three words here never go away from the local wisdom as the root to start an activity. That is why local wisdom must be understood as the moving step to begin and this is the great one in which every person in different region implement their activities.

\section{RESULTS AND DISCUSSIONS}

\section{A. The Local Values for National Education}

Local wisdom for national education interest is one of goal that should be achieved and this is the glue that is able to guide so that this nation has the identity as the pluralistic nation. The pluralistic nation means that the richness of nation in culture become the main factor that unifies all components of the nation in one republic. The local wisdom that is manifest in ideas, life view, science, and any kinds of life as the problem solver determines the way of the nation how it exists and continues its journey in traveling. Local wisdom is the life spirit from the local area for national interest that illustrates that the life spirit teaches the life behavior that should be internalized and become the life principles to be firm in building the nation. Local wisdom contributes towards national education.

The step to reach national education with the vision to embody the strong social indignity to empower all citizens in order to be able to respond the era challenge in the next phase is the strategic standpoint in implementing the local values in educating the nation. The goal of national education with the spirit of local values has been in line with the national goal for dignity. It means that in order to deliver the local wisdom values to students, school as the formal education has the role for that

\section{B. Inserting Local Wisdom into the National Curriculum}

In teaching and learning activity, especially in the classroom, it is very important to insert the local wisdom in order to support the national education goal and this is called the position of the national curriculum is strategic to develop and involve the local wisdom as the local material. There are two points of benefit by inserting local wisdom towards a national curriculum. The first one is that local identity is delivered to students so that they know their local identity in which they are from, they live, and they interact. The second is that the goal of national education in order to introduce and teach the national identity is reached in which Indonesia with many varieties of culture is internalized to students. They do not only know their own identity but also know the other local identities from other regions in this republic.

As the effort to develop the local wisdom into the local curriculum based on the national curriculum, there are several principles that should be paid attention (The Minister 
Education and Culture Act Number 81A, 2013 about The Implementation of Curriculum):

\section{- Holistic}

The local content development is implemented is based on competence, performance, and life skill.

\section{- Contextual}

The local content development is based on culture, potency, and local problem.

\section{- Integrated}

The local content development should be integrated with the environment of the school, home industry, and industry.

\section{- Appreciative}

The result of local content in the product should be celebrated in exhibition, competition, and reward at school and region.

\section{- Flexible}

The sort of local content chosen by the school for delivery should be flexible with the condition and characteristics of the school.

\section{- Long life education}

Local content does not only orients to learning result, but also drives the students to learn in long life education.

\section{- Benefit}

Local content orients to maintain and develop the local culture to respond the global challenge.

Those principles above become the ones in bringing the local wisdom in line with the national interest for education and enlightenment. The education that has the objective to develop the intellectual intelligence and academic brightness through any discipline should be supported with local wisdom role in guiding the students to have the history root that is called local wisdom. In curriculum development, it is to be conducted in a holistic manner. The contextual in curriculum development is the other factor in determining the success of local contents in delivering to the students.

In curriculum design in which the local content is the basic consideration in developing the curriculum, the capability in integrating the school condition and its environment that forms the curriculum identity should be well formulated so that the goal of local and national interest is attained. What the students get by taking part in learning and teaching activities is based on the local and national curriculum should be completed with the teacher's involvement to perform what the students obtain for giving a reward. The appreciation is necessary to create the students' self-confidence that he/she is successful to do the best. As the process of learning, whatever the students have in learning can be considered as the long life education. What they get can be rich and internalized in their life wherever and whenever they are. In a word, local wisdom integrated into the curriculum has the significant contribution towards national interest in which education should be able to respond the global challenge.

\section{Designing Local Curriculum based on National Curriculum}

Local curriculum as the basic base for implementing the local interest for building nation should be designed must be based on the national curriculum. The local wisdom that has been discussed previously should be integrated into the curriculum and it can be conducted through:

\section{- Bottom Up}

The implementation of local content based education can be built step by step starting from the schools in which they have the authority to determine the kind of local content in line with need analysis need. The determination of local content should be followed by designing the curriculum based on the need identification and supporting resources. The sort of local content that has been implemented should be analyzed for finding out the related studies.

\section{- Top Down}

The local government has the material of local content that is to be designed in curriculum based on the need to conduct at school. The developing team of local content can analyze the core and content of local content holistically. After the results have been found, the team formulates the recommendations to the authority in order to create the policy about local content that is to conduct based on the local interest.

As the continuation of such such design, local content can be developed as follows:

- Identifying and analyzing the curriculum context

Identification of curriculum context covers identity, potency, excellence, local wisdom, dan local need.

- Determining the sort of local content to develop

The sort of local content involves four component, namely social, culture and political aspect; entrepreneurship, ecological education; and other local identities:

- Local culture deals with the basic views, social values, social values, and artifact manifest in material and behavior that are sacred for the local context.

- Entrepreneurship is the local content dealing with education aiming to develop the entrepreneurship and selfcapacity.

- Ecological education and other local identities are the local subjects to introduce the better environment, the sensitivity towards the environment, and environment potency development.

- The combination of local culture, entrepreneurship, ecology, and another local identity can create the life skill.

\section{3. Determining the local content material}

The determination of local content material is to enlist and analyze any documents of local content to conduct based on the 
need and characteristics of the local. It should be based on the following criteria:

- The availability of students' development level psychologically;

- Teachers' competence and human resources' availability;

- The availability of supporting infrastructure;

- Supporting the religion and nation dignity;

- $\quad$ Supporting the social order and safety;

- $\quad$ Being proper to conduct at school;

- The availability of local situation and condition;

- $\quad$ Fulfilling the local needs, namely potency, excellence, and local need;

- Developing the basic competence being oriented towards core competence;

- Designing local content syllabus.

\section{CONCLUSION}

The local wisdom manifest in local curriculum becomes the need and necessity to respond the challenge global. National education translated in national curriculum has to able to drive the implementation of local wisdom in imprinting the local values to students. Designing the local content based on the local wisdom that is documented in the curriculum should be conducted.

The local wisdom in the local curriculum is based on the local needs at every school in line with the environment supporting the goal of education to create the civilized nation. In other words, local wisdom is the response to respond the global challenge so that the local identity is not lost; however the national interest is manifest and maintained in the educational objectives.

\section{REFERENCES}

[1] Dellors, Jacques et all. Learning: The Treasure Within. UNESCO Publishing.

[2] Constitution 1945.

[3] The Act Number 20, 2003 about National Education System.

[4] Kilpatrick. William H. Philosophy of Education. New York: MacMillan Coy. 1957.

[5] Lodge, Rupert C. Philosophy of Education. New York: Harper\&Brothers. 1947.

[6] Nata, Abudin Nata. Filsafat Pendidikan Islam. Jakarta: Gaya Media Pratama. 2005.

[7] The Act number 19, 2005 about National Standard.

[8] Muzakki and Puji Yanti Fauziah. Implimentasi Pembelajaran Anak Usia Dini Berbasis Budaya Lokal di PAUD Full Day School. Jurnal Pendidikan dan Pemberdayaan Masyarakat. Volume 2 - Nomor 1, March 2015, pp. 39-54.

[9] Fajarini, Ulfah. Peranan Kearifan Lokal dalam Pendidikan Karakter. Sosio Didaktika. Vol. 1, No. 2, December 2014. P. 123-130.

[10] F.X, Rahyono. Kearifan Budaya dalam Kata. Jakarta: Wedatama Widyasastra, 2009.

[11] Koentjaraningrat. Pengantar Ilmu Antropologi. Jakarta: Aksara Baru. 2009.

[12] Habibah, Neneng. Fungsi Saman Pada Masyarakat Pandeglang (Studi Kasus di Desa Giri Jaya Kecamatan Saketi dan Desa Batu Ranjang Kecamatan Cipeucang Kabupaten Pandeglang). PENAMAS, Vol. XXI, No.1, 2008. P. 88. 